\title{
A Study on Body Weight and Benefit Cost Ratio of Weaned Kids of Sirohi Goat Fed with Different Levels of Concentrates
}

\author{
Hanuman Lal Nehra ${ }^{1 *}$, Athar Uddin ${ }^{1}, \operatorname{Vinod}$ Bhateshwar $^{2}$ and Hitesh Muwal ${ }^{3}$ \\ ${ }^{1}$ Department of Livestock Production Management, Sri Karan Narendra Agriculture \\ University, Jobner (Raj.) India \\ ${ }^{2}$ Department of Animal Husbandry \& Dairying, Banaras Hindu University, \\ Varanasi (U.P.) India \\ ${ }^{3}$ Maharana Pratap University of Agriculture and Technology, Udaipur (Raj.) India \\ *Corresponding author
}

\section{Keywords}

Concentrates, Body weight, Benefit cost ratio and Sirohi goat kids

\section{Article Info}

Accepted:

05 February 2020

Available Online:

10 March 2020

\section{A B S T R A C T}

The present research work was carried out to study the effect of concentrate feeding on body weight and benefit cost ratio of weaned kids of Sirohi goat. Twenty four kids of Sirohi breed between 3-4 months age were randomly selected on the basis of uniform body weight, age and divided into 3 groups of 8 kids each at the goat farm of S.K.N. College of Agriculture, Jobner. Group $\mathrm{T}_{1}$ served as control supplemented with $50 \mathrm{~g}$ concentrate per kid per day for 3 months. Group $\mathrm{T}_{2}$ (treatment) supplemented with 50, 100 and $150 \mathrm{~g}$ concentrate and $\mathrm{T}_{3}$ (treatment) with 100,150 and $200 \mathrm{~g}$ concentrate per head per day for $1^{\text {st }}, 2^{\text {nd }}$ and $3^{\text {rd }}$ month, respectively. Other management practices were similar for each group. Fodder of khejri loom was offered ad-libitum to all groups. Body weight of kids was recorded weekly. Group $\mathrm{T}_{3}$ fed with more quantity of concentrate achieved the highest $(85.77 \mathrm{~g} /$ day $)$ average weekly weight gain followed by $\mathrm{T}_{2}(69.22 \mathrm{~g} /$ day $)$ and control group $\mathrm{T}_{1}\left(61.33 \mathrm{~g} /\right.$ day). Maximum average total weight gain per kid was observed in group $\mathrm{T}_{3}$ $(7.72 \mathrm{~kg})$ followed by $\mathrm{T}_{2}(6.23 \mathrm{~kg})$ and least was found in $\mathrm{T}_{1}(5.52 \mathrm{~kg})$. It is concluded from the results that there was significant increase in weekly and monthly weight gain $(\mathrm{P} \leq 0.01)$ of kids supplemented with higher quantity of concentrate in diet. Thus from above findings it can be concluded that $T_{2}$ and $T_{3}$ treatments showed significantly improved body weight in Sirohi kids and higher level $\left(\mathrm{T}_{3}\right)$ was relatively the best level in terms of both biological and economical returns.

\section{Introduction}

Goats have multifaceted utility as a livestock species and play significant role in rural economy. Rearing of goats is very useful for small and marginal farmers and landless labourers especially in the areas, where crops and dairy farming are not economical. Goat plays an important role in generating employment in rural areas. Being small in size, they do not require any large management skills and can be easily handled and managed by women and children. Goats can survive in areas with low quality 
vegetation. In India, goats are mainly fed on crop residues, green fodder, top feeds and non-conventional feed resources.

Goat meat has no religious taboo and the market for it is well established. They are traditionally raised by poverty stricken village people in a secondary system of grazing on harvested fellow land, along the road and canal sides, community pasture land without any supplementation.

For the poor farmers who are unable to maintain large ruminants, goat justifies its designation as "the poor man's cow". Under the changing agro-geo-climatic conditions and depleting resources for livelihood, the goat has tremendous potential to be projected as the 'Future Animal' for rural prosperity. As per $19^{\text {th }}$ livestock census 2012, the Goat population of India is 135.17 million, which is $26.40 \%$ of total livestock population of the country. The goat population reduced by 3.82 percent in 2012 over 2007 census, India rank $2^{\text {nd }}$ in total goat meat production and average yield of meat of indigenous goat is 10.74 kg/animal (Annual report 2015-2016, Department of Animal Husbandry ,Dairy and Fisheries, GOI).

Supplementation of concentrates is important for growth and productivity of goats (Kochapakdee et al., 1994). By feeding good quality concentrate we can satisfy requirement of both protein and energy. Increasing concentrate levels in kid diet results in increased live weight, as well as carcass weight (Ryan et al., 2007).

However, reports on the nutrient requirements are scanty and very little information is available particularly on the contribution of dietary protein and energy to the performance of growing kids under farm conditions and the cost benefit of feeding additional concentrates has not been fully explored in goat-production systems and needs to be evaluated. The quality and quantity of concentrate fed to growing kids has got very much importance for their maintenance and weight gain. Many farmers in India rear goats for the purpose of meat production and for them the growth is most valuable.

Supplementation of concentrate is required for faster weight gains, but it should also be economical. So it is necessary to decide the adequate level of concentrate for faster growth rate.

Most of the small farmers rear goats by keeping animals free for grazing on local grass, bushes, tree leaves and kitchen waste only. These are deficient mainly in protein and energy. For obtaining optimum growth of kids, it is essential to supplement required quantity of concentrate.

The kids after weaning suffers with the deficiency of nutrients which hamper their growth and their available feeds need supplementation of concentrate to increase the growth rate and economic returns.

\section{Materials and Methods}

\section{Place of work}

The experiment was conducted at goat farm, S.K.N. college of Agriculture, S.K.N. Agriculture University Jobner, District Jaipur, (Rajasthan, India).

\section{Selection of experimental animals and design}

Twenty four Sirohi goat kids of either sex having approximately uniform body weight and age group (4 months) were selected. These kids were divided into three equal groups consisting of eight kids in each group and the study was carried out for a period of 
thirteen weeks. The experiment was conducted using randomized block design.

\section{Housing and management of experimental animals}

Similar housing and managemental facilities were provided to all the groups. Animals were penned in well-ventilated enclosures for the experiment.

\section{Feeding of experimental animals}

The concentrate mixture in pelleted form was obtained from local market Concentrate and roughages were fed separately to each kid in all treatment groups. The concentrate was fed once in a day at 10:00 am. Whereas, the roughage (khejri loom) was offered at 10:30 am and 4:00 pm to all treatment groups. Adlibitum clean drinking water was available round the clock to all treatment groups.

\section{Body weight}

All the experimental kids were weighed early in the morning, before offering the feed, at weekly intervals upto 13 weeks from the commencement (4 months of age) of the experiment. Weighing was carried out by digital weighing balance/electronic. The experimental kids were weighed individually at the start of the experiment and at weekly intervals thereafter, up to 90 days on weighing balance.

\section{Benefit cost ratio of concentrate feeding}

It was calculated on the basis of additional cost involved in supplementation of concentrate and value of additional weight gain. The cost of additional concentrate mixture was calculated as per the prevailing market rates. The cost of additional weight gain was also calculated as per the prevailing rate of kids on $\mathrm{kg}$ live weight basis.

\section{Statistical analysis}

Statistical analysis was carried out by standard statistical methods RBD and the calculation of ANOVA was done. This formula was given by Fisher and Yates (1950). Superscripts are used for significantly difference in means by DMRT method. Duncan's new multiple range test (DMRT) is a multiple comparison procedure developed by David B. Duncan in 1955.

\section{Results and Discussion}

\section{Body weight}

Table 3 shows the total gain in body weight $5.52,6.23$ and $7.70 \mathrm{~kg}$ for groups $\mathrm{T}_{1}, \mathrm{~T}_{2}$ and $\mathrm{T}_{3}$, respectively. There was significant difference $(\mathrm{P} \leq 0.01)$ between three treatments. The total gain in weight of kids from group $\mathrm{T}_{3}$ was significantly $(\mathrm{P} \leq 0.01)$ higher than kids from group $\mathrm{T}_{1}$ and $\mathrm{T}_{2}$. However, total gain in weight of kids from group $T_{2}$ was significantly $(\mathrm{P} \leq 0.01)$ higher than that of $\mathrm{T}_{1}$. Guru et al., (2004) observed that at the end of the experiment kids with higher levels of concentrate supplementation tended to maintain heavier body weights. Anil Kumar et al., (2009) also recorded at the end of experiment that the body weight of the ewes which were fed higher amount of concentrates was significantly heavier than ewes receiving less amount of concentrates. The results obtained in present trial were in agreement with these findings.

\section{Benefit cost ratio}

The input- output relationship is presented in Table 4. Total concentrate intake for groups $\mathrm{T}_{1}, \mathrm{~T}_{2}$ and $\mathrm{T}_{3}$ was $4.30,8.50$ and $12.50 \mathrm{~kg} / \mathrm{kid}$, respectively, during a period of three months of feeding concentrate. It was observed that the cost incurred was Rs.86.00, 170.00 and 250 per kid for groups, $\mathrm{T}_{1}, \mathrm{~T}_{2}$ and $\mathrm{T}_{3}$, 
respectively, indicating higher cost of feeding for group $T_{3}$ than $T_{2}$ and $T_{1}$. Total live weight achieved at the end of experiment was 16.57, 17.31 and $18.73 \mathrm{~kg} / \mathrm{kid}$ for $\mathrm{T}_{1}, \mathrm{~T}_{2}$ and $\mathrm{T}_{3}$, respectively. Additional weight gain for $\mathrm{T}_{2}$ and $\mathrm{T}_{3}$ was 0.74 and $2.16 \mathrm{~kg}$, respectively. Additional Income realizable from total gain in weight during trial period for treatment groups $\mathrm{T}_{2}$ and $\mathrm{T}_{3}$ was Rs. 222.00 and 648.00 per kid and additional profit from total weight gained was Rs.138.00 and 484.00 rupees, respectively. Thus, the extra profit of Rs.346.00 per kid can be obtained due to feeding 100, 150 and $200 \mathrm{~g}_{\text {in }} \mathrm{T}_{3}$, followed by Rs 138.00 due to feeding of 50, 100 and $150 \mathrm{~g}$ in $\mathrm{T}_{2}$ than feeding of $50 \mathrm{~g}$ concentrate in control group.

Table.1 Distribution of experimental Sirohi goat kids

\begin{tabular}{|c|c|c|}
\hline Treatments & No. of Animals & Average body weight (in kg) \\
\hline $\mathbf{T}_{\mathbf{1}}$ & 08 & $11.05 \pm 0.80$ \\
\hline $\mathbf{T}_{\mathbf{2}}$ & 08 & $11.08 \pm 0.71$ \\
\hline $\mathbf{T}_{\mathbf{3}}$ & 08 & $11.03 \pm 0.78$ \\
\hline
\end{tabular}

Table.1 Feeding schedule of weaned kids of Sirohi goat

\begin{tabular}{|l|c|c|c|}
\hline \multicolumn{1}{|c|}{$\begin{array}{c}\text { Experimental period } \\
\text { (days) }\end{array}$} & $\mathbf{T}_{\mathbf{1}}$ & $\mathbf{T}_{\mathbf{2}}$ & $\mathbf{T}_{\mathbf{3}}$ \\
\hline $\mathbf{0 - 3 0}$ & Concentrate supplementation & gram/head/day \\
\hline $\mathbf{3 1 - 6 0}$ & 50 & 50 & 100 \\
\hline $\mathbf{6 1 - 9 0}$ & 50 & 100 & 150 \\
\hline
\end{tabular}

Table.2 Chemical composition (\%DM Basis) of concentrate mixture

\begin{tabular}{|l|l|l|}
\hline S.N. & Nutrients & Percentage \\
\hline 1. & Total digestible nutrient (TDN) & $75 \%$ \\
\hline 2. & Crude protein (CP) & $18 \%$ \\
\hline 3. & Crude fibre (CF) & $10 \%$ \\
\hline 4. & Common salt (CS) & $1.0 \%$ \\
\hline 5. & Mineral mixture(M.M.) & $2.0 \%$ \\
\hline
\end{tabular}

Table.3 Average total weight gain $(\mathrm{kg} /$ week) of Sirohi kids in different groups

\begin{tabular}{|l|c|c|c|}
\hline & $\mathbf{T}_{\mathbf{1}}(\mathbf{M e a n} \pm \mathbf{S E})$ & $\mathbf{T}_{\mathbf{2}}(\mathbf{M e a n} \pm \mathbf{S E})$ & $\mathbf{T}_{\mathbf{3}}(\mathbf{M e a n} \pm \mathbf{S E})$ \\
\hline Initial body weight (kg) & 11.05 & 11.08 & 11.03 \\
\hline Final Body Weight $(\mathbf{k g})$ & 16.57 & 17.31 & 18.73 \\
\hline Total gain in weight & $5.52^{\mathrm{c}} \pm 0.14$ & $6.23^{\mathrm{b}} \pm 0.20$ & $7.70^{\mathrm{a}} \pm 0.24$ \\
\hline Weight gain/day/kid & $0.061^{\mathrm{b}} \pm 0.04$ & $0.069^{\mathrm{b}} \pm 0.03$ & $0.085^{\mathrm{a}} \pm 0.01$ \\
\hline
\end{tabular}


Table.4 Benefit cost ratio of Sirohi goat kids

\begin{tabular}{|l|l|l|l|}
\hline Attributes & T1 & T2 & T3 \\
\hline Initial body weight(kg) & 11.05 & 11.08 & 11.03 \\
\hline Final Body Weight(kg) & 16.57 & 17.31 & 18.73 \\
\hline ADG(gm) & 61.33 & 69.22 & 85.55 \\
\hline Total concentrate intake (kg/kid) & 4.30 & 8.50 & 12.50 \\
\hline Cost of concentrate/kid (Rs) 20/kg & 86 & 170 & 250 \\
\hline Additional concentrate ration cost & - & 84 & 164 \\
\hline Additional weight gain (kg) & - & 0.74 & 2.16 \\
\hline Cost of live weight @ Rs 300/-per kg & 4971 & 5193 & 5619 \\
\hline Gross Benefit (Rs) & - & 222 & 648 \\
\hline Net Benefit (Rs) & & 138 & 484 \\
\hline Extra Benefit (Rs) & - & - & 346 \\
\hline
\end{tabular}

Similar observations were reported by Guru et al., (2004) who concluded that of all levels of supplementation of concentrate for feeding of growing kids, higher level $(450 \mathrm{~g} / \mathrm{h} / \mathrm{d})$ was relatively the best level in terms of both biological and economical returns. Haddad (2005) also observed that higher concentrate diets had reduced production costs compared to lower concentrate diets fed to kids. The results are in agreement with Jabbar and Anjum (2008) who recorded that higher concentrate level in diet (forage to concentrate ratio of 25:75) most appropriate for economical mutton production from Lohi lambs.

On the basis of the present investigation, it may be concluded that feeding concentrate at the rate $100,150,200 \mathrm{~g}$ per day per kid is useful. This higher level of concentrate feeding improved the absolute body weight of growing kids and also resulted in improved feed utilization, along with increased gross profit per kid. Further it was concluded that growing kid, may be supplemented with higher level of concentrate which improved the body weight, the feed utilization and ultimately the profit to the farmer.

\section{References}

Anil Kumar, R., Thiruvenkadan, A. K. and
Iyue, M. 2009. Influence of feeding regimes from lamb hood on productive and reproductive performance of Sandyno ewes. Indian Journal of Animal Sciences, 79(5): 511-513.

Annual report 2015-16, Department of Animal Husbandry, Dairying and Fisheries, Ministry of Agriculture, GOI, Livestock Population. 19th Livestock Census, Department of Animal Husbandry, Dairying and Fisheries, M/o Agriculture, GOI.

Fisher, R. A. and Yates, F. 1950. Statistical tables, Oliver and Boyd, Edinburgh, London. p.p. 146.

Guru, M., Tesfaye, L., Sisay, A., Dadi, H. and Assefa, E. 2004. Growth performance of arsi-bale kids supplemented with different levels of concentrate. African Journal of Livestock Extension, 3: 8286.

Haddad, S. G. 2005. Effect of dietary forage: concentrate ratio on growth performance and carcass characteristics of growing Baladi kids. Small Ruminant Research, 57(1): 43-49.

Jabbar, M. A. and Anjum M. I. 2008. Effect of diets with different forage to concentrate ratio for fattening of lohi lambs. Pakistan Journal of Veterinary Science, 28(3): 150-152. 
Kochapakdee, S., Pralomkam, S., Saitanoo, A. and Norton, B. W. 1994. Productivity of female goat grazing newly established pasture with varying levels of supplementary feeding. AsianAustralian Journal of Animal Science,
7: 289-293.

Ryan, S. M., Unruh, J. A., Corrigan, M. E., Drouillard, M. M. and Seyfert, M. 2007. Effects of concentrate level on carcass traits of Boer crossbred goats. Small Ruminant Research, 73: 67-76.

\section{How to cite this article:}

Hanuman Lal Nehra, Athar Uddin, Vinod Bhateshwar and Hitesh Muwal. 2020. A Study on Body Weight and Benefit Cost Ratio of Weaned Kids of Sirohi Goat Fed with Different Levels of Concentrates. Int.J.Curr.Microbiol.App.Sci. 9(03): 383-388.

doi: https://doi.org/10.20546/ijcmas.2020.903.045 